\title{
ABOUT THE COMPARISON OF THE STATE AUTHORITY AND SOCIAL ORGANIZATION BY INCAS AND AZTECS
}

\author{
Tarmo Kulmar
}

\begin{abstract}
During the period under consideration (1438-1532) the Inca state in Peru was politically a highly centralized empire with strong central government. Its social structure was that of an early class society with some communal traits; the government's intervention in social life was prevalent, village communities were put in the service of the government, horizontal mobility was regulated and vertical mobility was all but non-existent. It represented a socalled early totalitarian state.

The Aztec state in Mexico, during the period under consideration (14271519), was a confederation with weak central authority where the core of the confederation used conquered territories as a sort of economic backup. Their social organization represented an early class society with strong communal traits, little interference from the government in the daily life of the community, few opportunities for horizontal mobility, but vertical mobility was quite possible. As such it was a state that had retained many features of a military democracy.
\end{abstract}

Key words: Aztecs, confederation, early totalitarian state, Empire, Incas, Mexico, military democracy, Peru

\section{INTRODUCTION}

This article gives an overview of the political organization and social structure of the Inca Empire in Peru and the Aztec one in Mexico during their final, expansionist stage. There are some differences in the way the material is presented in the case of the Incas and Aztecs, owing to differences in their political history. While from its early stages, until its final period, the Inca Empire was basically the same ever-expanding state structure under the leadership of the Quechuan upper class or Incas, in the case of the Aztec Empire a significant change took place in its structure - sovereign Aztec city-states formed a triple alliance which began to implement a policy of expansion. However, the social stratigraphy and main features of the expansion of these states are described in a similar manner. Conclusions are drawn on the basis of comparison of the material. The author relies on the principal chronicles from the Conquista period as well as the works of several major researchers. ${ }^{1}$ 


\section{THE POLITICAL AND SOCIAL ORGANIZATION OF THE INCA STATE DURING ITS EXPANSIONIST PERIOD (1438-1532)}

\subsection{Territorial structure and government system of the empire}

Tahuantinsuyu ('Land of the Four Quarters') consisted of four provinces (suyu); in the centre, where the corners of these provinces met, lay the capital, Cuzco. The provinces were: Chinchaysuyu (North-West Peru to Ecuador), Antisuyu (north-eastern part, mainly the eastern slopes of the Andes and the flatlands of the rain forests), Collasuyu (south-eastern highlands, incl. Lake Titicaca, Bolivia, the north-western part of Argentina and the northern part of Chile) and Cuntisuyu (the southern and western parts of Peru down to the Pacific coast). The provinces were further sub-divided into smaller regions (see further, e.g., Cobo 1996: 189-202).

At the head of the state stood the sovereign or Sapa Inca ('emperor') who was worshipped as the son of the sun god. The succession passed from the emperor to the worthiest of his sons by his principal consort. When the heir apparent reached his majority, he was given a chance to prove himself as a coruler. The emperor had absolute power, but in practice the success of his rule depended on how well he managed to please the upper classes. Of particular importance were the interests of the warlords. The emperor was assisted by the state council, consisting of the heir apparent, some close relatives who had high official positions, the commander-in-chief of the army, and the high priest of the sun god. The actual power structure was strictly hierarchical and nontransparent (Murra 1958).

In conformity with the ethnic and social dualism of the ancient Incan tribal society, the highest offices in the provinces were doubled, with two parallel functionaries being appointed to each post; this was to ensure that these two aided each other and simultaneously kept a close watch on each other. It is likely that a similar division of power existed in other public offices. Among the emperor's councillors were the vice-regents of the four provinces as well as provincial governors whose hierarchical position depended on the size of their provinces, i.e. the number of taxable families who were organized into groups of ten families (Wedin 1965: 34-46). Commoners were admitted only to the lowest administrative positions. The hierarchy of officials was recognizable by their visible symbols of power - both in terms of their conduct and clothing. Loyal leaders of conquered tribes were allowed to keep their positions, but they ruled in name only and were accountable to the Inca representatives of the central government. Their children had to be sent to the capital as hostages in order to ensure that they were raised and educated in the spirit of ruling ideology (Cunow 1937: 58-81). 


\subsection{Tools of government: statistics and communications}

Special officials (quipucamayoc) were trained to keep a tally of the population and resources, including tax accounting. These officials used quipu, a recording device based on cords and knots. The information thus recorded was numeric, based on the decimal system, and encoded by the number and colour of cords attached to the main string and the shape and number of knots in the cords. Presumably the quipu was not designed to record long verbal texts. To keep account of taxable subjects, the population of the empire was divided into groups of ten families, which in turn formed bigger units according to the decimal system (see further, e.g., Cieza de León 1988: ch. LIX, LX, XCIII, CV).

The most important centres of the empire were connected by a well developed road network. Two main roads ran parallel, one along the coast and the other up in the Andean range from Chile to Ecuador. From these there branched numerous side roads. Since the Incas used neither wheeled vehicles nor riding animals, communication between settlements was effected by couriers and transporters relaying between numerous post stations (tampu). Messages were also conveyed by smoke or light signals (Espinoza 1990: 345-398).

\subsection{Social categories ${ }^{2}$}

2.3.1. Aristocracy consisted of three ranks. Ranking the highest were the Incas or Quechuan hereditary aristocracy who were sufficiently numerous to keep the state under their control. The next class were half-blood Incas or panaca, as well as the elite of ethnic groups in the region surrounding Cuzco or the socalled 'Incas by privilege'. Namely, the original concept of a village community had undergone significant changes in the core of the empire. In Cuzco and its environs, the traditional village community or ayllu had been transformed into panaca. Panaca, as a privileged ayllu, included thousands of descendants of emperors, people who in principle were counted among nobility and from whose ranks public officials were recruited. The third group consisted of the upper classes of the conquered tribes who were loyal to the Incas and who had been granted privileges and given certain influence in local affairs.

2.3.2. The majority of the population who worked in the fields, bred cattle or worked as craftsmen in villages, were the working class - hatunruna.Ayllu, or the village community, was the foundation of the social organization of the Inca state. Ayllus were the building blocks of regions and provinces. The separation between aristocracy and commoners was strict and the vertical mobility, from lower to upper ranks, within communities was normally not possible. Even the horizontal mobility, i.e. choosing a career within the society, was strictly regulated and controlled by the authorities. 
Agricultural land and cattle were the source of the greatest material wealth in the Inca Empire. The ultimate landowner was the state, that is to say the emperor. Reallocation and use of arable land was regulated by government. Most of the cultivated land was at the disposal of the ayllu and was divided into three parts. One part was periodically re-distributed according to the number of village communities and the size of farmer families in each community. The crop produced on this part formed the livelihood of the farmers' families. The other two parts of the arable land were cultivated collectively by the village community. The produce from there was expropriated and its purpose was to maintain the government and court, the multitudes of officials, army, priesthood, craftsmen (camayoc), as well as the non-working members of the community - the elderly and the disabled. The lands meant to sustain the hereditary nobility and panaca living in or near Cuzco were worked by the retainers (yanacuna) resettled there. As the number of the panaca was constantly growing, each emperor had to conquer new lands to sustain them. The emperor also gave his loyal officials grants of land. Thus, a constant shortage of arable land was one of the driving forces behind the policy of expansion.

In addition to taxes in kind that the communities of farmers, cattle breeders and craftsmen had to pay from their produce, the ayllu had to do mandatory public service (mita) - build roads, bridges, fortifications and irrigation systems, participate in military campaigns as soldiers or auxiliary workforce, as well as serve as couriers and transporters of goods. Only married, ablebodied adults were drafted into that service. In their absence their normal everyday work was done by the rest of their ayllu. Starting from emperor Pachacutec Yupanqui in mid-15th century, three new social groups had emerged whose status was hereditary and who were directly dependent on the state: these were yanacuna, aclla and mitmac.

2.3.3. The yanacuna class comprised retainers of various different categories, who formerly have been mistaken for slaves. The yana worked solely in the mita public service on state or imperial objects, on the estates of the hereditary aristocracy, as well as on the estates of the panaca near the capital. The origin of the yana is not clear; however, it is possible that the class developed on the basis of the ayllu who had been deprived of their hatunruna rights as a punishment. The status of yana was hereditary and irrevocable.

2.3.4. Acllas were beautiful young women chosen from among the ayllus. They were sent to live in special sanctuaries in the most important cities of the empire. They were not allowed to marry nor have children. They did handicraft for the upper classes, served in the temples or became concubines to members of the royal family. Sometimes acllas were also sacrificed to gods. In 
general, Incas practiced human sacrifice only on occasions of the highest importance, because the general utilitarian view prescribed that humans were first and foremost meant to be the labour force. The status of the acllas, as chosen women, was exclusive and limited to the woman's lifetime.

2.3.5. The mitmac class was formed as whole ayllus were either (1) resettled into newly conquered territories in order to consolidate power, or (2) resettled from newly conquered territories into old imperial territories in order to prevent rebellion, or (3) resettled for the purposes of working newly arable land. Also, mitmac service involved resettling numerous craftsmen into the capital city. The status of mitmac was hereditary and irrevocable (Oberem 1990; Rostworowski de Díez Canseco 1988: 181-234).

\subsection{Expansionist policy and the army ${ }^{3}$}

Incas were quick to consolidate their rule over conquered territories. They used not only military but also diplomatic means to do so. On many occasions they took advantage of the tensions and disagreements between local chieftains or bribed them with gifts and estates. The incorporation of borderlands was finalized with the building of fortifications and manning of garrisons. Territories conquered by war or forceful diplomacy were integrated closely into the fabric of the empire. Great emphasis was laid on building up loyalty to the government: tax rates were regulated, elementary needs of the people were met, unnecessary violence was avoided, new ethnic groups were allowed to worship their traditional gods, frequent religious holidays provided entertainment, a special government service was responsible for spreading approved ideologies. As a result, during the Spanish conquest Peruvian tribes did not go over to the conquerors' side, but met them with steadfast resistance.

The Incas had a large permanent army. Professional military consisted of certain belligerent ethnic groups who were kept permanently at arms, such as the Cañari Indians who were relocated to the vicinity of Cuzco and exempted from all other duties or services. Warriors of various tribes fought in the Inca army in their own tribal units, using their own weapons, bearing their distinguishing marking, and under their own commanders. Strong and healthy men were also drafted for military campaigns under mita service. Regiments consisting of two or three such units were under the command of Inca officers. Every other officer's post was doubled on the principle of dualism, whereby one could replace the other whenever needed, but they also kept each other under surveillance. Women were also drafted into the army; they fulfilled auxiliary duties. The military units of the Inca army were mobile and trained to move fast over difficult landscape. Spanish chroniclers of the 16th century 
have expressed admiration for their ability to fight. In the decisive battle of Cajamarca the Spanish side was only victorious due to surprise and cunning tactics (Busto Duthurburu 1981: 209-233).

\section{THE POLITICAL AND SOCIAL SYSTEM IN MEXICO IN THE 15TH AND EARLY 16TH CENTURIES}

\subsection{The basic political structure of the Aztec society ${ }^{4}$}

The main political units of Central Mexico were state-like formations with a defined territory, not unlike city-states. Each of these had an urban centre with palaces and temples, houses where upper classes lived, and government offices. Cities were surrounded by economic hinterland with villages and farms. City-states were densely populated. Often they formed confederate alliances for the purposes of aggression or defence. City-states were ruled by dynastic families. The majority of the population belonged to Nahuatl-speaking ethnic groups with similar religious beliefs and ceremonies, notably human sacrifice to feed gods so that these would keep the world going. The 'code of conduct' between city-states implied ensuring everybody free access to all temples and shrines of gods worshipped there, to public market places and trading areas, diplomatic immunity of emissaries and envoys, and observance of proper protocols upon declaring war. There was no permanent army. Young men received military training and were mobilized upon necessity (Vaillant 1949: 7585; Davies 1989: 115-159).

\subsection{Social structure of the Aztecs ${ }^{5}$}

The population was divided into two principal social classes. The upper class was for the most part formed by hereditary aristocracy (pilli) and accounted for approx. $10 \%$ of the population. Some vertical mobility between aristocracy and commoners was possible, on the basis of military prowess, which could result in commoners being given titles, nominations to public offices, tax exemptions or land grants. Thus, there developed a numerous class of non-hereditary aristocracy and lower ranks of priesthood.

3.2.1. Hereditary aristocracy consisted of numerous families that differed in their origin, property or power. Heads of families bore their historical titles involving the term 'lord' (teuctli). The head of an aristocratic family was usually chosen according to the male lineage, whereas account was also taken of military merit and position in the government structure. Tracing the lineage from the maternal line was also not out of the question. Heads of families were 
either elected by peers or appointed by the ruler. An aristocratic family and the seat of its head were known as tecalli - 'Noble House', incorporating an estate and vassals and retainers who were members of the minor branches of family. Estates (pillalli) were hereditary, often also passed down by female lineage. The teuctli or landowners could have multiple wives and own great riches, but many lower-ranking noblemen were poor and not so different from common farmers. The teuctli were exempt from taxes. Each major aristocratic family was, in essence, a largely independent economic unit whose head often had great political and legal influence. In fact the extent of a nobleman's power was determined by the number of his vassals.

3.2.2. Each city-state (tlatocayotl) had one or more rulers (tlatoani - 'speaker') belonging to the leading aristocratic families. The legitimacy of a tlatoani was determined by the merits of his forefathers in founding the state, and the ability to trace back one's lineage (through marriages) to the women of the ruling family of the earlier Toltec civilization. The order of succession depended on the practice of the aristocratic family who was in power. The ruler fulfilled the highest religious, administrative and judicial functions of state. Judges, higher and medium ranking officials and the top ranks of the religious hierarchy also came from hereditary aristocratic families.

3.2.3. The majority of the population were commoners (macehualtin - 'workers'), either farmers or craftsmen, whereas in most cases sons took over the trade of their fathers. Some of the commoners lived in the holdings of the nobility as retainers, others in caste-like corporative groups formed on the basis of kinship and profession (calpulli - 'big house'), working collectively on the lands belonging to temples, schools for young men or public institutions, and paying taxes. Such an extended family had common ownership of land, from which a plot was allocated for livelihood to each family unit. The other duty of each macehualtin was to fight in a war. Commoners could be rewarded for courage in war and thus make their way up on the social ladder. Ranking even lower than the workers was a group of free people who were despised for some reason, who had no right to own land and worked as a paid workforce on the land owned by their kinsmen.

3.2.4. There were also two kinds of slaves in Mexican city-states: some were cast into slavery as a punishment for a crime they had committed, others had sold themselves into slavery because of poverty. One could be freed from the status of a slave either by buying oneself out, or where the widow of the slave's owner decided to marry the slave. Prisoners of war were usually not kept as slaves - they were sacrificed to the gods. 
3.2.5. An isolated caste was formed by merchants (pochteca). They lived in a separate part of the town, married only among themselves and only their children could become pochteca. Merchants had the right to free movement, and therefore governments used them as spies and messengers. Highly qualified craftsmen and transport workers (tlamama - 'men of burden') also formed their specific professional corporations or castes.

3.2.6. Young men were educated in two types of schools. Attached to the most important temples were calmecacs, where children of nobility received training in theology, military matters, statesmanship as well as arts. Children of commoners were educated in telpochcalli where they were primarily taught to fight well in wars, but also received training in various practical skills (Hinz 1990; Prem 1999: 34-53; León-Portilla 1959: ch. V).

\subsection{The structure and policy of the Aztec state during its expansionist period $^{6}$}

\subsubsection{The Triple Alliance}

The Triple Alliance of Aztec states was created under the initiative of Itzcoatl, ruler of Tenochtitlan in the 1430s and it consisted of the states of Tenochtitlan, Acolhuacan (capital: Tetzcoco) and Tlacopan. At first the alliance had no political leadership, the ruler was determined in the course of negotiations. Because of the geographical location of the three capitals, each party of the alliance could arrange political matters within its region according to its own volition. Each of the three states was sovereign in domestic affairs and had its own government structures that were independent of those of the other parties. Foreign policy and military campaigns were co-ordinated between the three. In essence, appointing a successor to a deceased ruler was an interior matter and the sovereign right of each state in the alliance. The appointment merely required solemn recognition from the other two rulers.

In time Tenochtitlan became the leading city in the Triple Alliance. Officially, the alliance was governed by the state council residing in Tenochtitlan and made up of representatives of all cities of the confederation. However, the rulers of the founding city-states had a decisive vote: the tlatoani of Tetzcoco controlled legislation and the construction of public buildings, the tlatoani of Tlacopan was responsible for economy and handicraft, while the tlatoani of Tenochtitlan was in charge of foreign affairs and supreme command of the armies, therefore also bearing the title of tlacatecuhtli, 'lord of all men'. Formally, tlacatecuhtli was elected by the representatives of the twenty most important Aztec noble families, although in reality this position was hereditary. A tlacatecuhtli chose his successor in his lifetime, unlike in Tetzcoco, where 
only a son borne to the ruler by his principal wife could become the next tlatoani. Tlacatecuhtli was assisted by a regent or cihuacoatl who managed interior affairs and acted as chief judge. Tlacatecuhtli presided over a small state council comprising four other members besides the cihuacoatl, including the high priest of the Tenochtitlan chief god Huitzilopochtli (Carrasco \& Monjarás-Ruiz 1998; Zantwijk 1990).

\subsubsection{The policy of expansion and the army}

Within roughly a hundred years (1427-1519) the Aztecs managed to subjugate nearly all of Mexico, 38 states or city-states in all. However, the actual Aztec Empire was limited to the territory of the Triple Alliance - Tenochtitlan and its two allied cities. Other conquered areas were regarded only as taxable territories. These territories were independent in their domestic affairs, being ruled by local rulers, but they were under the surveillance of Aztec governors. The latter had to ensure, with the helpful presence of garrisons of the Triple Alliance, that the tribute was paid duly and in time. To collect the tribute, the Triple Alliance had a huge apparatus of officials, with offices in the capitals of conquered territories. The tribute payable to the alliance also included a certain number of people who were put into slavery or sent to Tenochtitlan to be sacrificed.

The main objective in a military campaign, aside from conquering territories, was not to slaughter enemies, but rather to capture as many prisoners as possible. Prisoners of war were sacrificed on the altars of the capitals of the Triple Alliance. When the Aztec Triple Alliance happened not to be at war with a neighbour, they invited a conquered territory to a so-called flowery war. It was a war game, similar to a real war in every aspect from the declaration of war to the Aztec victory that culminated in taking prisoners. 16th century chronicles and archaeological finds suggest tens of thousands of human sacrifices. Cities that rebelled against the Triple Alliance were destroyed. The Aztec occupants were met with such hatred that in 1519 the Spanish conquerors immediately found numerous allies in rebelling cities, which ultimately was one of the main reasons why the Aztec Empire was defeated, regardless of the bravery of the Aztec army (Vaillant 1949: 151-158).

\section{COMPARISONS}

\subsection{The scope of government control}

The Inca Empire was a state of strong centralized authority even before its expansionist period. All provinces of the Tahuantinsuyu territory were under government control in all essential aspects. 
The Aztec city-states consisted of urban power centres and economic backcountry. Even in their expansionist period the core of the empire was solely the Triple Alliance under the leadership of Tenochtitlan, and conquered territories were primarily subjected to their economic control.

\subsection{Methods of government, the extent of the ruler's control, and the order of succession}

The Inca state was an empire ruled by an emperor who had absolute power; he nominated the most able of his sons, by his principal wife, to be the heir to his throne.

The Aztec Empire was a confederation whose supreme ruler, a primus inter pares, was formally chosen by a tribal representative body, although in practice the succession passed down to one of the sons of the preceding ruler.

\subsection{Organs of government}

The Inca emperor was assisted by a small state council consisting of the heir apparent, commander-in-chief of the army and high priest. Executive power was conferred to the heads of various offices and governors appointed by the emperor. The great state council, an advisory body, consisted of provincial viceregents appointed by the emperor from among higher ranks of aristocracy, as well as army commanders. Tribal representative bodies had lost their importance and ceased to exist.

The Aztec supreme ruler was assisted by a state council consisting of six members, including the regent who had extensive powers. The supreme ruler delegated some functions to the other rulers of the Triple Alliance. He had an advisory body in the form of a state council consisting of the leaders of all cities of the core states. The council of tribal chiefs also had extensive authority, incl. that of formally electing and also deposing the ruler.

\subsection{Taxation}

Incas divided their produce into three shares: one for the producer, one for the emperor or landowner, and the third portion was meant to sustain the nonworking members of the community, priesthood, soldiers, craftsmen and those required for public service, which in essence was also meant to serve the interests of the empire. In addition, they had to serve regularly under the mandatory public service obligation. Professional warriors and people resettled to the periphery were exempt from taxes. Precise accounts were kept on the amount of taxes and taxable people. The authorities made sure that at least minimum means of subsistence were left to the producers. 
The Aztec community had to give away all their produce to the landowner, who used it for himself and to maintain his workers, paid tribute to the state, and sold a part of it to merchants. The landowner could be either an aristocratic family or a working community. In case of war the landowner had to put up a certain number of soldiers and provide their equipment. Public works were done by slaves or the lowest-ranking free members of the community. Conquered territories were required to pay excessive tribute, which caused social unrest.

\subsection{Social strata}

The Inca class society consisted of aristocracy and commoners. In addition to hereditary aristocracy, there was a numerous group of 'new nobility' (halfblood descendants of emperors) as well as aristocracy 'by privilege' (tribal chiefs loyal to the Inca). The ranks of commoners produced three specialized social strata - resettled families, chosen women and those who cultivated land on aristocracy's estates. There were no slaves in the Inca society.

The Aztec society consisted of aristocracy, a class of free commoners, and slaves. In addition to hereditary aristocracy there were aristocrats by merit who had won their titles by prowess in wars. Among common people several groups could be distinguished on the basis of relations of ownership and rates of taxation. Some workers belonged to exclusive castes based on profession. The poorest members of community could fall into slavery. Prisoners of war were sacrificed to gods.

\subsection{Horizontal and vertical mobility}

In the Inca society horizontal mobility (i.e. free choice of career) was strictly regulated and controlled, whereas vertical mobility (being raised to a higher social level) was highly exceptional.

In the Aztec society horizontal mobility was rare, due to the caste system of professions, whereas vertical mobility was much more frequent as it occurred through courage in war.

\subsection{Army}

Incas had a permanent army of professional soldiers and those mobilized under mandatory public service. The army was maintained by the state. Auxiliary works were done by community members by way of mandatory public service. 
The Aztecs had no permanent army. Their army was mobilized upon necessity and all young men received military training. Each landowner had to procure a prescribed number of warriors and provide their equipment. Auxiliary work was done by slaves and community members of the lowest status.

\subsection{Specific characteristics of the expansion process}

Incas annexed new territories by military or diplomatic means. New borderlands were integrated into the empire by way of population transfer.

Aztecs used military means to conquer new territories, but did not integrate these into their empire.

\subsection{Government's tactics with regard to conquered territories}

Incas made every effort to ensure the loyalty of the population of new territories, using various political and economic measures to achieve that.

Aztecs, on the other hand, viewed new territories as a sort of economic backcountry of the confederation, imposing excessive taxes on the population.

\subsection{Assessment}

The Inca Empire was an early totalitarian state with a strong central government and well organized government apparatus; its ordinary population was first and foremost regarded as useful labour force.

The core state of the Aztec confederation was an early class society with strong traits of military democracy; conquered areas were not treated as forming political parts of the state, but as an economic resource.

\section{CONCLUSION}

During the period under consideration (1438-1532), the Inca state in Peru was politically a highly centralized empire with a strong central government. Its social structure was that of an early class society with some communal traits; government's intervention in social life was prevalent, village communities were put in the service of the government, horizontal mobility was regulated and vertical mobility was all but nonexistent. It represented a so-called early totalitarian state.

The Aztec state in Mexico, during the period under consideration (14271519), was a confederation with weak central authority where the core of the confederation used conquered territories as a sort of economic backcountry. Their social organization represented an early class society with strong com- 
munal traits, little interference from the government in the daily life of the community, few opportunities for horizontal mobility, but vertical mobility was quite possible. As such it was a state that had retained many features of a military democracy.

\section{ACKNOWLEDGEMENTS}

This article has been supported by grant no. 5374 of the Estonian Science Foundation.

\section{NOTES}

${ }^{1}$ See further about research history: Prem, Hanns 1989: 33-52; 69-76; 137-177; 183200.

${ }^{2}$ See further, e.g., Garcilaso de la Vega, Inca 1988: book IV, ch. 12-14; book V, ch. 1-10, $13-16$.

3 See further, e.g., Ayala, Felipe Guaman Poma de 1980: 122-151; Garcilaso de la Vega, Inca 1988: book III, ch. 4; book V, ch. 12.

${ }^{4}$ See further, e.g., Sahagún, Fray Bernardino de 1990: book VIII; see also Durán, Fray Diego 1967: vols. I, II

5 See further, e.g., Sahagún, Fray Bernardino de 1990: book IX; see also Durán, Fray Diego 1967.

${ }^{6}$ See further, e.g., Sahagún, Fray Bernardino de 1990: book XII; Acosta, José de 1991: 173ff; see also Durán, Fray Diego 1967.

\section{REFERENCES}

Acosta, José de 1991. Das Gold des Kondors: Berichte aus der Neuen Welt 1590 und Atlas zur Geschichte ihrer Entdeckung. = Historia Natural y moral de las Indias [1590]. Herausgegeben und übertragen von Rudolf Kroboth, Peter H. Meuerer, Cornelis van Wytfliet. Stuttgart \& Wien: Edition Erdmann in K. Thienemanns Verlag.

Ayala, Felipe Guaman Poma de 1980. El Primer Nueva Corónica y Buen Gobierno [1615]. In: J. V. Murra \& R. Adorno (eds.). Comments by J. L.Urioste. Colección América nuestra. Ciudad de México: Edición al Cuidado de Martí Soler Portada de Anhelo Hernández.

Busto Duthurburu, José Antonio del 1981. Perú incaico. Lima: Librería Studium S.A.

Carrasco, Pedro \& Monjarás-Ruiz, Jesús 1998. La estructura interna de la Triple Alianza. Arqueología Mexicana, Vol. VI, No. 32: Poder y política en el México prehispánico. México, pp 42-49.

Cieza de León, Pedro 1988. La Crónica del Perú [1553]. Lima: Promoción Editorial Inca S.A.

Cobo, Father Bernabé 1996. History of the Inca Empire = Historia del Nuevo Mundo [1653]. 5th ed.Transl. and ed. by Roland Hamilton from the holograph manu- 
script in the Biblioteca Capitular y Colombina de Sevilla. Foreword by John Howland Rowe. The Texas Pan American series. Austin: University of Texas Press.

Cunow, Heinrich 1937. Geschichte und Kultur des Inkareiches. Ein Beitrag zur Kulturgeschichte Altamerikas. Amsterdam: Elsevier.

Davies, Nigel 1989. Die Azteken. Meister der Staatskunst-Schöpfer hoher Kultur. rororo 8522: rororo-Sachbuch. Reinbek bei Hamburg: Rowohlt.

Durán, Fray Diego 1967. Historia de las Indias de Nueva España e islas de la Tierra Firme [1579-1581], Vols. 1-2. Biblioteca Porrua 36-37. Ciudad de México: Editorial Porrua.

Espinoza Soriano, Waldemar 1990. Los Incas. Economía, sociedad y Estado en la era del Tahuantinsuyo. 2nd ed. Lima: Amaru Editores.

Garcilaso de la Vega, Inca 1988. Comentarios Reales de los Incas [1609], Vols. 1-3. Lima: Editorial Mercurio S.A.

Hinz, Eike 1990. Das Aztekenreich: Soziale Gliederung und institutioneller Aufbau. In: U. Köhler (ed.) Altamerikanistik. Eine Einführung in die Hochkulturen Mittelund Südamerikas. Ethnologische Paperbacks. Berlin: Dietrich Reimer Verlag, S. $189-206$.

León-Portilla, Miguel 1959. La filosofia Náhuatl. Estudia en sus fuentes. Publicación del Instituto de Historia 52. México: Universidad Nacional Autonoma de México \& Instituto de Histórica \& Seminario de Cultura Náhuatl.

Murra, John V. 1958. On Inca political structure. In: V. Ray (ed.) Systems of political Control and Bureaucracy in Human Societies. Seattle: University of Washington Press, pp. 30-41.

Oberem, Udo 1990. Das Inkareich unter politischem, sozialem und wirtschaftlichem Aspekt. In: U. Köhler (Compiler and ed.) Altamerikanistik. Eine Einführung in die Hochkulturen Mittel- und Südamerikas. Ethnologische Paperbacks. Berlin: Dietrich Reimer Verlag, pp. 467-492.

Prem, Hanns 1989. Geschichte Altamerikas. Oldenbourg Grundriss der Geschichte, 23. München: R. Oldenbourg Verlag.

Prem, Hanns 1999. Die Azteken. Geschichte, Kultur, Religion. Beck'sche Reihe 2035. München: Verlag C. H. Beck.

Rostworowski de Díez Canseco, María 1988. História del Tahuantinsuyu. Historia Andina / Instituto de Estudios Peruanos 13. Lima: Instituto de Estudios Peruanos.

Sahagún, Fray Bernardino de 1990. Aus der Welt der Azteken = Historia general de las cosas de Nueva España [1558-1580]. Foreword by J. Rulfo. Transl. by L. Schultze Jena \& E. Seler \& S. Dedenbach-Salazar-Sáenz. Frankfurt am Main: Insel Verlag.

Vaillant, Georges Clapp 1949 = Vaijan, Dzhordzh Klapp. Istorija atstekov = Aztecs of Mexico. Moscow: Izdatel'stvo inostrannoj literatury.

Wedin, Åke 1965. El sistema decimal en el imperio incáico. Estudio sobre estructura político, división territorial y población. Serie del Instituto Ibero-Americano de Gotemburgo. Madrid: Insula.

Zantwijk, Rudolf A. M. van 1990. Politische Gliederung am Vorabend der Conquista. In: U. Köhler (ed.) Altamerikanistik. Eine Einführung in die Hochkulturen Mittelund Südamerikas. Ethnologische Paperbacks. Berlin: Dietrich Reimer Verlag, pp. 179-188. 